\title{
Actinobacteria from Extreme Niches in Morocco and Their Plant Growth-Promoting Potentials
}

\author{
Ahmed Nafis ${ }^{1,2, *}$, Anas Raklami ${ }^{1}{ }^{1}$, Noura Bechtaoui ${ }^{1}$, Fatima El Khalloufi ${ }^{3}$, \\ Abdelkhalek El Alaoui ${ }^{1}$, Bernard R. Glick ${ }^{4}$, Mohamed Hafidi ${ }^{2,5}$, Lamfeddal Kouisni ${ }^{2}$, \\ Yedir Ouhdouch ${ }^{1,2}$ and Lahcen Hassani ${ }^{1}$ \\ 1 Laboratory of Biology and Biotechnology of Microorganisms, Faculty of Sciences Semlalia, Cadi Ayyad \\ University, Marrakech 40000, Morocco \\ 2 Agrobiosciences \& Fertilizers Program, University Mohammed IV Polytechnic (UM6P), Benguerir 43150, \\ Morocco \\ 3 University Sultan Moulay Slimane, Polydisciplinary Faculty of Khouribga, BP. 145, Khouribga 25000, \\ Morocco \\ 4 Department of Biology, University of Waterloo, 200 University Avenue South, Waterloo, ON N2L 3G1, \\ Canada \\ 5 Laboratory of Ecology and Environment (L2E), Faculty of Science Semlalia, Cadi Ayyad University, \\ Marrakesh 40000, Morocco \\ * Correspondence: ahmed.nafis@edu.uca.ac.ma; Tel.: +212-61-017-0760
}

Received: 22 June 2019; Accepted: 14 August 2019; Published: 20 August 2019

\begin{abstract}
The objectives of this study were to assess actinobacterial diversity in five Moroccan extreme habitats and to evaluate their plant growth-promoting (PGP) activities. The soil samples were collected from different locations, including soils contaminated with heavy metals, from a high altitude site, from the desert, and from a marine environment. In total, 23 actinobacteria were isolated, 8 from Merzouga sand soil; 5 from Cannabis sativa rhizospheric soil; 5 from Toubkal mountain; 4 from a Draa sfar mining site; and 1 from marine soil. Based on their genotypic classification using $16 \mathrm{~S}$ rRNA gene sequences, 19 of all belonged to the genus Streptomyces ( $82 \%$ ) while the rest are the members of the genera Nocardioides (4.5\%), Saccharomonospora (4.5\%), Actinomadura (4.5\%), and Prauserella $(4.5 \%)$. Isolates Streptomyces sp. TNC-1 and Streptomyces sp. MNC-1 showed the highest level of phosphorus solubilization activity with 12.39 and $8.56 \mathrm{mg} / \mathrm{mL}$, respectively. All 23 isolates were able to solubilize potassium, and $91 \%$ of them could grow under nitrogen-free conditions. The ability of the isolated actinobacteria to form indole-3-acetic acid (IAA) ranged from 6.70 to $75.54 \mu \mathrm{g} / \mathrm{mL}$ with Streptomyces sp. MNC-1 being the best IAA producer. In addition, all of the actinobacteria could produce siderophores, with Saccharomonospora sp. LNS-1 synthesizing the greatest amount $(138.92 \mu \mathrm{g} / \mathrm{mL})$. Principal coordinate analysis revealed that Streptomyces spp. MNC-1, MNT-1, MNB-2, and KNC-5; Saccharomonospora sp. LNS-1; and Nocardioides sp. KNC-3 each showed a variety of high-level plant growth-promoting activities. The extreme environments in Morocco are rich with bioactive actinobacteria that possess a variety of plant growth-promoting potentials that can further benefit green and sustainable agriculture.
\end{abstract}

Keywords: actinobacteria; extremophile; plant growth-promoting bacteria

\section{Introduction}

Microorganisms can colonize various ecological niches, including extremophilic habitats, due to their adaptive features, including structural as well as functional adaptations [1]. Several novel species have been isolated from these extreme habitats, including Streptomyces thinghirensis [2] and Streptomyces youssoufiensis [3]. Morocco possesses diverse ecosystems, many of which are considered extreme, 
such as high mountain peaks, arid deserts, and polymetallic mines, but the actinobacterial diversity of these extreme habitats is lacking. These Moroccan untapped habitats represent hostile ecosystems enriched with immense biodiverse values worthy of being explored. Actinobacteria which occur in both terrestrial and aquatic habitats are among the most common groups of Gram-positive filamentous bacteria with high guanine-cytosine (G-C) content in their genomes and are able to form spores [4]. They have also been found to colonize various ecosystems, including extreme environments, and to produce extensive secondary metabolites with major importance for biotechnology and agriculture [5]. These bacteria have very high physiological and ecological plasticity, which makes them well adapted to survive in environments where the conditions may be extreme [6]. Actinobacteria which have incredible abilities to persist under extreme conditions have long been the focus of many studies and have been harnessed as valuable sources of novel bioactive metabolites [7]. The exploration of extreme habitats could even find new taxa. However, their ecological functions, which may be of benefit to agriculture, are not well known.

One of the primary sources of income in Morocco is agriculture, which requires a high input of chemical fertilizers resulting in a concomitant high cost of crop production. On the other hand, microorganisms play a significant role in soil fertility through the management of nitrogen $(\mathrm{N})$, phosphorus $(\mathrm{P})$ and potassium $(\mathrm{K})$ cycles in the soil. For instance, some of the diverse bacteria called plant growth-promoting (PGP) rhizobacteria, which live within the rhizospheres of plants, can support plant growth by fixing atmospheric nitrogen and solubilizing inorganic $\mathrm{P}$ and $\mathrm{K}$ [8]. As with other PGP bacteria, actinobacteria also employ both direct and indirect mechanisms to influence plant growth and protection. The direct mechanisms involve the production of vigorous factors for crop growth, such as phytohormones and advantageous actions such as $\mathrm{N}$ fixation, $\mathrm{P}$ solubilization, and iron acquisition [9]. Additionally, PGP actinobacteria indirectly influence plant growth by controlling and minimizing the deleterious effects of external stresses from either biotic or abiotic sources [10]. Moreover, the use of actinobacteria as biofertilizers or biocontrol agents for improving and protecting crop yield has been highlighted in several research studies [11,12]. Streptomyces is the most abundant genus of actinobacteria found in the plant rhizosphere, and it often promotes plant growth by producing regulators such as indole acetic acid (IAA) that aid root growth, producing siderophores that can improve nutrient uptake, or through biocontrol activity to protect host plants from phytopathogens [13].

Furthermore, extremophilic actinobacteria have been thoroughly investigated for their unique mechanisms of adaptation to extreme environments, and also because they produce several unusual metabolites especially for the inhibition of human pathogens [14,15]. Numerous studies have investigated the ecology of actinobacteria, typically within common habitats [16]. However, very little data is available on the diversity and ecological functions of actinobacteria inhabiting soils from Moroccan extreme sites. The aims of this study were to: (1) investigate the generic diversity of culturable actinobacteria in different Moroccan extreme ecosystems (i.e., Toubkal mountain, Merzouga desert, Rif rhizospheric soil, Marchica marine environment and Draa Sfar mining site); and (2) evaluate the PGP potentials (i.e., $\mathrm{N}$ fixation, solubilization of $\mathrm{P}$ and $\mathrm{K}$, and production of IAA and siderophores) of these bacteria.

\section{Materials and Methods}

\subsection{Study Sites, Sample Collection, and Isolation of Actinobacteria}

Five soil samples were collected at a depth of about 6 to 8 inches from different Moroccan ecosystems (Table 1). Immediately after their collection, the samples were stored at $4{ }^{\circ} \mathrm{C}$ before the isolation of actinobacteria. 
Table 1. Origins and characteristics of the five Moroccan sites explored.

\begin{tabular}{|c|c|c|c|c|c|c|}
\hline \multirow{2}{*}{ Sample } & \multirow{2}{*}{ Origin } & \multirow{2}{*}{ Site Characteristic } & \multirow{2}{*}{$\begin{array}{l}\text { Geographic } \\
\text { Coordinate }\end{array}$} & \multicolumn{3}{|c|}{ Physicochemical Property } \\
\hline & & & & $\mathrm{pH}$ & $\mathrm{EC}(\mathrm{mS} / \mathrm{ms})$ & TOC (\%) \\
\hline $\begin{array}{l}\text { Mountain } \\
\text { soil }\end{array}$ & Toubkal & $\begin{array}{l}\text { Highest mountain } \\
\text { peak in Morocco } \\
\text { and the Arab world }\end{array}$ & $\begin{array}{c}4167 \mathrm{~m} ; \\
31.05917^{\prime \prime} \mathrm{N} \\
-7.91583^{\prime \prime} \mathrm{W}\end{array}$ & 7.9 & 2.14 & 1.02 \\
\hline Desert soil & Merzouga & $\begin{array}{l}\text { Highest dunes in } \\
\text { Morocco }\end{array}$ & $\begin{array}{c}150 \mathrm{~m} ; \\
31.147643^{\prime \prime} \mathrm{N} \\
-3.974280^{\prime \prime} \mathrm{O}\end{array}$ & 8.04 & 0.95 & 0.96 \\
\hline $\begin{array}{l}\text { Rhizospheric } \\
\text { soil }\end{array}$ & Rif & $\begin{array}{l}\text { Rhizosphere of } \\
\text { Cannabis sativa } \\
\text { grown in Rif plains }\end{array}$ & $\begin{array}{l}34.920059^{\prime \prime} \mathrm{N} \\
-4.561078^{\prime \prime} \mathrm{O}\end{array}$ & 8.62 & 4.99 & 1.58 \\
\hline Marine soil & Marchica & $\begin{array}{l}\text { Largest lagoon in } \\
\text { Morocco }\end{array}$ & $\begin{array}{c}35.156468^{\prime \prime} \mathrm{N} \\
-2.904342^{\prime \prime} \mathrm{W}\end{array}$ & 8.31 & 20.41 & 0.34 \\
\hline Mining soil & Draa Sfar & $\begin{array}{l}\text { Significant potential } \\
\text { for polymetallic ore }\end{array}$ & $\begin{array}{l}31.704270^{\prime \prime} \mathrm{N} \\
-8.135748^{\prime \prime} \mathrm{W}\end{array}$ & 5.4 & 6.5 & 1.13 \\
\hline
\end{tabular}

EC: electrical conductivity; TOC: total organic carbon.

Each soil sample $(10 \mathrm{~g})$ was suspended in $90 \mathrm{~mL}$ of a sterile saline solution $(0.9 \%(w / v) \mathrm{NaCl}$ in distilled water). The homogenous soil suspension was 10-fold serially diluted with the same sterile saline solution, and $0.1 \mathrm{~mL}$ of each dilution was spread onto saline nutrient agar for the marine soil [17] and onto Bennett agar [18] or chitin-vitamin agar [19] for the rest soil samples. The media were supplemented with nalidixic acid $(100 \mu \mathrm{g} / \mathrm{mL})$ and cycloheximide $(50 \mu \mathrm{g} / \mathrm{mL})$ to prevent the growth of Gram-negative bacteria and fungi, respectively. The seeded agar plates were incubated for 3 weeks at $28^{\circ} \mathrm{C}$ and the colonies that developed were examined by light microscopy. After isolation, the purified isolates were stored in $25 \%(w / v)$ glycerol at $-20{ }^{\circ} \mathrm{C}$ as the primary stocks.

\subsection{Molecular Identification of Actinobacterial Isolates}

Each actinobacterial isolate was grown in $100 \mathrm{~mL}$ of Bennett broth at $28^{\circ} \mathrm{C}$ for 5 days. Its genomic DNA was extracted using a Bacterial DNA kit (MPure ${ }^{\mathrm{TM}}$, Ottawa, ON, Canada) according to the manufacturer's instructions. The 16S rRNA gene was amplified by PCR using universal primers: FD1 (5' AGAGTTTGATCCTGGCTCAG3') [20] and S17 (5'CGGTCACGTTCGTTGC3') [21]. The PCR reaction with a final volume of $50 \mu \mathrm{L}$ contained GoTaq Reaction Buffer (Promega ${ }^{\circledR}$ ), $1.5 \mathrm{mM}$ of $\mathrm{MgCl}_{2}$, $200 \mu \mathrm{M}$ of each desoxyribonucleotides (dNTP), $1 \mu \mathrm{M}$ of each primer, $0.5 \mathrm{U}$ of Taq DNA polymerase, and $1 \mu \mathrm{L}(500 \mathrm{ng})$ of the purified bacterial DNA template. The amplification was carried out in a thermocycler (Thermo Scientific ${ }^{\mathrm{TM}}$, Munich, Germany) with the following profile: an initial denaturation at $95{ }^{\circ} \mathrm{C}$ for $5 \mathrm{~min}, 30$ cycles of denaturation at $95^{\circ} \mathrm{C}$ for $30 \mathrm{~s}$, annealing at $53^{\circ} \mathrm{C}$ for $30 \mathrm{~s}$, extension at $72{ }^{\circ} \mathrm{C}$ for $1.5 \mathrm{~min}$, and a final extension at $72{ }^{\circ} \mathrm{C}$ for $5 \mathrm{~min}$. PCR products were separated using $1 \%$ $(w / v)$ agarose gel electrophoresis and visualized by ultraviolet (UV) fluorescence (UV-transilluminators, CA, USA).

The same primers were then used separately in two sequencing reactions from the two ends of the amplified fragment (Eurofins Scientific, Berlin, Germany). The 16S rDNA sequences were compared with the publicly available nucleotide sequences in the EzBioCloud database [22]. The sequences were aligned using CLUSTAL W [23] in the Molecular Evolution Genetics Analysis (MEGA) software version 5.0 [24]. Phylogenetic trees were inferred using neighbor-joining analyses [25] based on the Tamura 3-parameter model. 


\subsection{Evaluation of Plant Growth-Promoting Potentials}

\subsubsection{P Solubilization}

Each actinobacterial isolate was grown in $100 \mathrm{~mL}$ of National Botanical Research Institute's phosphate growth medium devoid of yeast extract (NBRIY) broth, supplemented with tricalcium phosphate $\left(\mathrm{Ca}_{3}\left(\mathrm{PO}_{3}\right)_{2}\right)$ as a source of inorganic phosphate [26]. The inoculum was incubated at $28{ }^{\circ} \mathrm{C}$ on a rotatory shaker at $180 \mathrm{rpm}$. The $\mathrm{pH}$ of the culture broth was measured after $48 \mathrm{~h}$ up to $196 \mathrm{~h}$ with a pH meter. Sterile NBRIY broth without inoculation served as a baseline control. Bacterial cells and other insoluble materials were removed by centrifugation at $4830 \times \mathrm{g}$ for $20 \mathrm{~min}$, and the resulting supernatant was filtered through a $0.45 \mu \mathrm{m}$ filter. The concentration of soluble $\mathrm{P}$ in the supernatant was measured using the molybdenum blue method described by Nagul et al. [27].

\subsubsection{K Solubilization}

The ability of each actinobacterial isolate to solubilize $\mathrm{K}$ was tested using Aleksandrov agar medium (composition per 1:5 g glucose, $0.5 \mathrm{~g} \mathrm{MgSO}_{4} \cdot 7 \mathrm{H}_{2} \mathrm{O}, 0.1 \mathrm{~g} \mathrm{CaCO}_{3}, 0.006 \mathrm{~g} \mathrm{FeCl}_{3}, 2 \mathrm{~g} \mathrm{Ca}_{3} \mathrm{PO}_{4}$, $20 \mathrm{~g}$ agar powder, and $5 \mathrm{~g}$ of Mica powder as a source of inorganic potassium) [28]. A single colony of each actinobacterium was streaked onto the agar medium and incubated at $28{ }^{\circ} \mathrm{C}$ for 7 days. The development of a clear zone surrounding a bacterial colony indicated a positive test for $\mathrm{K}$ solubilization. The level of K-solubilizing activity was determined by the size of the clear zones formed.

\subsubsection{N Fixation}

Each actinobacterial culture was previously grown in Bennett broth at $28{ }^{\circ} \mathrm{C}$ with shaking at $125 \mathrm{rpm}$ for 5 days. The liquid culture was centrifuged at $6574 \times \mathrm{g}$ for $10 \mathrm{~min}$. The cell pellets were resuspended in sterile $0.9 \%(w / v)$ saline solution and streaked onto a solid N-free medium (NFM), then incubated for 7 days [29]. N-fixing isolates are those able to grow on this medium.

\subsubsection{IAA Production}

Each actinobacterial isolate was grown in $100 \mathrm{~mL}$ of Luria Bertani (LB) broth [30] supplemented with $1.02 \mathrm{~g} / \mathrm{L}$ of L-tryptophan as a precursor of IAA. The culture broth was incubated at $28{ }^{\circ} \mathrm{C}$ with shaking at $125 \mathrm{rpm}$ for 4 days. Then, the bacterial cells were removed by centrifugation at $8217 \times g$ for $10 \mathrm{~min}$. The Salkowski's reagent $\left(10 \mathrm{mM} \mathrm{FeCl}_{3}, 35 \%\right.$ perchloric acid) and 2 drops of phosphoric acid were added to $1 \mathrm{~mL}$ of the bacterial supernatant. The test solution was subsequently incubated for $30 \mathrm{~min}$ in the dark before its absorbance was measured at $530 \mathrm{~nm}$ [31]. Sterile LB medium served as a blank. The amount of IAA produced was calculated using a standard curve of known IAA concentrations.

\subsubsection{Siderophore Estimation}

The supernatant $(0.5 \mathrm{~mL})$ of each actinobacterial isolate growing in LB broth at $28^{\circ} \mathrm{C}$ for 5 days [32] was mixed with $0.5 \mathrm{~mL}$ of Chrome Azurol S (CAS) reagent. After $20 \mathrm{~min}$ of incubation at ambient temperature, the optical density of the test solution was measured at $630 \mathrm{~nm}$ [33]. The amount of siderophore produced was determined from a standard curve prepared with desferrioxamine mesylate as described by Baakza et al. [34].

\subsection{Statistical Analysis}

The results presented are means \pm standard deviations (SDs) of four biological replicates per treatment for the in vitro tests. Statistical comparison of means was performed using a one way analysis of variance (ANOVA) with least significant difference (LSD) available in the COSTAT software. The results were compared using a Student, Newmann, Keuls (SNK) test. Significant differences at 
$p<0.05$ are indicated. P solubilization, siderophore, IAA production and their correlation with isolated actinobacteria were subjected to principal component analysis (PCA) using XLStat software.

\section{Results and Discussion}

\subsection{Actinobacterial Diversity in Different Moroccan Extreme Environments}

We isolated 23 actinobacteria from five soil samples collected from various Moroccan ecosystems (Table 2). All actinobacterial isolates belonged to one of five genera, namely: Streptomyces, Nocardioides, Saccharomonospora, Actinomadura, and Prauserella (Table 2 and Figure 1). The genus Streptomyces was found to be the most abundant actinobacteria, representing $82 \%$ of the total isolates. We also isolated some rare actinobacteria belonging to Nocardioides (4.5\%), Saccharomonospora (4.5\%), Actinomadura (4.5\%) and Prauserella (4.5\%) genera. Actinomadura sp. NDS-2 was isolated from Draa sfar, a heavy metal polluted area containing lead, copper, zinc, and zinc oxide [35]. Three other actinobacteria belonging to Streptomyces and Prauserella genera were also isolated from the same site. This result is consistent with previous research that reported metal-resistant strains belonging to several actinobacterial genera, such as Streptomyces, Amycolatopsis [36], Nocardia, Micromonospora [37], and Frankia [38].

Table 2. Molecular and plant growth-promoting (PGP) characteristics of the isolated actinobacteria.

\begin{tabular}{|c|c|c|c|c|c|c|}
\hline \multirow[b]{2}{*}{$\begin{array}{l}\text { Site of } \\
\text { Isolation }\end{array}$} & \multicolumn{4}{|c|}{ Molecular Characteristics } & \multicolumn{2}{|c|}{ PGP Characteristics } \\
\hline & $\begin{array}{l}\text { Isolate } \\
\text { Code }\end{array}$ & $\begin{array}{c}16 \text { rRNA Gene } \\
\text { Accession Number }\end{array}$ & $\begin{array}{l}\text { Similarity } \\
\%\end{array}$ & Closest Type Strain & $\begin{array}{c}\mathrm{N}_{2} \\
\text { Fixation }\end{array}$ & $\begin{array}{c}\text { K } \\
\text { Solubilization }\end{array}$ \\
\hline \multirow{3}{*}{$\begin{array}{l}\text { Rhizospheric } \\
\text { soil }\end{array}$} & KNC-2 & MN161858 & 96.06 & Streptomyces actinomycinicus RCU-197 & +++ & +++ \\
\hline & KNC-3 & MN161861 & 98.23 & Nocardioides albus KCTC9186 ${ }^{\mathrm{T}}$ & ++ & ++ \\
\hline & KNC-4 & MN161862 & 99.38 & Streptomyces chartreusis NBRC $12753^{\mathrm{T}}$ & +++ & ++ \\
\hline \multirow{5}{*}{ Desert soil } & MNB-2 & MN164450 & 99.31 & Streptomyces luteus NRRL B-59117 & +++ & +++ \\
\hline & MNB-3 & MN164447 & 94.12 & Streptomyces pratensis $\mathrm{CH} 24^{\mathrm{T}}$ & + & ++ \\
\hline & MNC-1 & MN161860 & 97.76 & Streptomyces asenjonii KMN35-1 ${ }^{\mathrm{T}}$ & ++ & ++ \\
\hline & MNC-2 & MN161865 & 99.17 & Streptomyces plicatus DSM $40319^{\mathrm{T}}$ & +++ & ++ \\
\hline & MNC-3 & MN161850 & 98.65 & Streptomyces violascens ISP5183 ${ }^{\mathrm{T}}$ & +++ & +++ \\
\hline \multirow{4}{*}{ Mining soil } & NDS-1 & MN161854 & 97.80 & Streptomyces asenjonii KMN35-1 ${ }^{\mathrm{T}}$ & + & + \\
\hline & NDS-2 & MN161853 & 98.03 & Actinomadura napierensis $\mathrm{B} 60^{\mathrm{T}}$ & +++ & ++ \\
\hline & NDS-3 & MN161864 & 99.68 & Streptomyces albidoflavus DSM $40455^{\mathrm{T}}$ & - & - \\
\hline & NDS-4 & MN161855 & 98.42 & Prauserella soli $12-833^{\mathrm{T}}$ & - & + \\
\hline \multirow{5}{*}{$\begin{array}{l}\text { Mountain } \\
\text { soil }\end{array}$} & TNB-1 & MN164448 & 96.05 & Streptomyces jietaisiensis DSM $41866^{\mathrm{T}}$ & +++ & + \\
\hline & TNB-2 & MN164449 & 98.85 & Streptomyces albidoflavus DSM $40455^{\mathrm{T}}$ & +++ & + \\
\hline & TNB-3 & MN161859 & 97.11 & Streptomyces rutgersensis ATCC $3350^{\mathrm{T}}$ & ++ & + \\
\hline & TNC-1 & MN161852 & 98.56 & Streptomyces violascens ISP5183 ${ }^{\mathrm{T}}$ & +++ & +++ \\
\hline & TNC-2 & MN161856 & 98.38 & Streptomyces hydrogenans DSM $40586^{\mathrm{T}}$ & +++ & +++ \\
\hline
\end{tabular}

-: Absence of activity; +: low activity; ++: moderate activity and +++: high activity. T: Type strain 


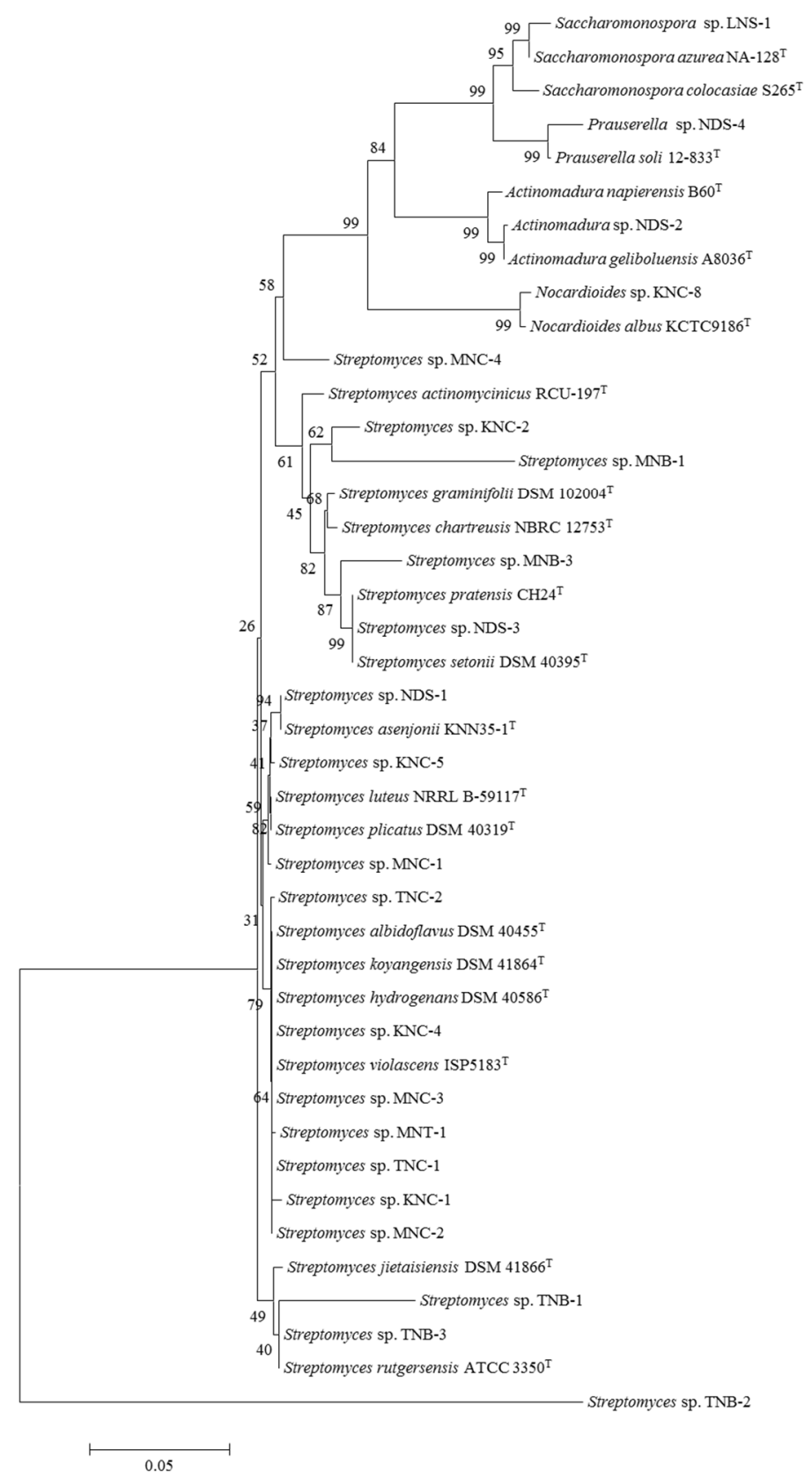

Figure 1. Neighbor-joining phylogenetic tree based on $16 \mathrm{~S}$ rRNA gene sequences (>1300 nt) showing the relationships between 23 actinobacteria isolated from several Moroccan habitats and their closely related species. The numbers at the nodes indicate the levels of bootstrap support based on neighbor-joining analyses of 1500 resampled data sets. Bar, 0.05 substitution per nucleotide position.

Samples from the arid region "Merzouga" (desert soil), known for high temperatures, nanomolar concentrations of nutrients, low water activity, and intense radiation [39], permitted the isolation of eight isolates belonging to the Streptomyces genus. The same result was found for the Toubkal mountain sample with five Streptomyces isolates. These results are in agreement with the studies of Harwani, [40] and Santhanam et al. [41], who reported that some Streptomyces species (e.g., Streptomyces deserti and Streptomyces bullii) were isolated from the hyper-arid Atacama Desert. Kurapova et al. [42] have previously reported isolating a moderately thermophilic xerotolerant Streptomyces sp. 315 from Mongolian desert soil. These authors also isolated other species of Streptomyces with Actinoplanes and Geodermatophilus from the Negev and Mojave desert soils [42]. In addition, the Algerian Saharan soil 
reveled the existence of several actinobacterial strains, with some of them belonging to rare genera such as Actinomadura, Nonomuraea, Nocardiopsis, Saccharothrix, Spirillospora, and Streptosporangium [43-45].

Unlike the mountain and the desert soils, the rhizospheric soil of Cannabis sativa exhibited the presence of five actinobacterial isolates. Among them we could identify Nocardia, which is a rare actinobacterium, in agreement with the study of Khamna et al. [46] who demonstrated that the rhizospheric soil of 16 medicinal plants provided a rich source of actinobacterial diversity. Overall, $89 \%$ of all actinobacteria that were found in this study belonged to the genus Streptomyces, supporting the suggestion that Streptomyces is the predominant actinobacterial genus in the soil $[47,48]$.

The composition of the actinobacterial community may be affected by several environmental parameters, such as salinity [49], temperature [50], and heavy metals [51]. Furthermore, the apparent diversity may be affected by the nutrient composition of the culture media used during the isolation process [52]. In the marine soil sample, we successfully isolated a rare actinobacterium belonging to Saccharopolyspora. This isolate was able to grow in seawater, consistent with several studies that have discussed the isolation and diversity of actinobacteria in marine areas [53,54]. New marine actinobacterial taxa have been recovered, including Salinispora, the first marine obligate actinomycete isolated from ocean sediments [55], as well as from a sponge [56]. Many authors have reported Streptomyces as the major actinobacterial population in both terrestrial [57] and marine ecosystems [58,59]. Nevertheless, marine actinobacteria may have different characteristics from terrestrial ones and therefore might produce novel bioactive compounds, including new antibiotics [60].

\subsection{PGP Potentials of Extremophilic Actinobacteria}

The use of PGP actinobacteria as an alternative to chemical fertilizers is potentially a key strategy to enhance sustainable plant production and protection. The solubilization of inorganic $\mathrm{P}$ by the newly isolated actinobacteria is shown in Figure 2. After 8 days of incubation, the available P released ranged from 2.11 to $12.39 \mathrm{mg} / \mathrm{mL}$ with variations among different isolates. Streptomyces sp. TNC-1 and Streptomyces sp. MNC-1 were the most efficient isolates in releasing soluble P into the culture broth (12.39 and $8.56 \mathrm{mg} / \mathrm{mL}$, respectively). The P solubilization by these isolates was often accompanied by a significant drop in the $\mathrm{pH}$ from an initial $\mathrm{pH}$ of 7.5 to as low as 4.83 , after $192 \mathrm{~h}$ of incubation. With Streptomyces sp. TNC-1, the highest amount of soluble $\mathrm{P}$ was associated with a decrease in the $\mathrm{pH}$ to 4.93. These data indicate that the solubilization process of $P$ is consistent with the bacterial excretion of substances that acidified the culture broth [61]. Several reports indicate that organic acid (OA) and siderophores production are among the mechanisms underlying inorganic P solubilization [62,63].

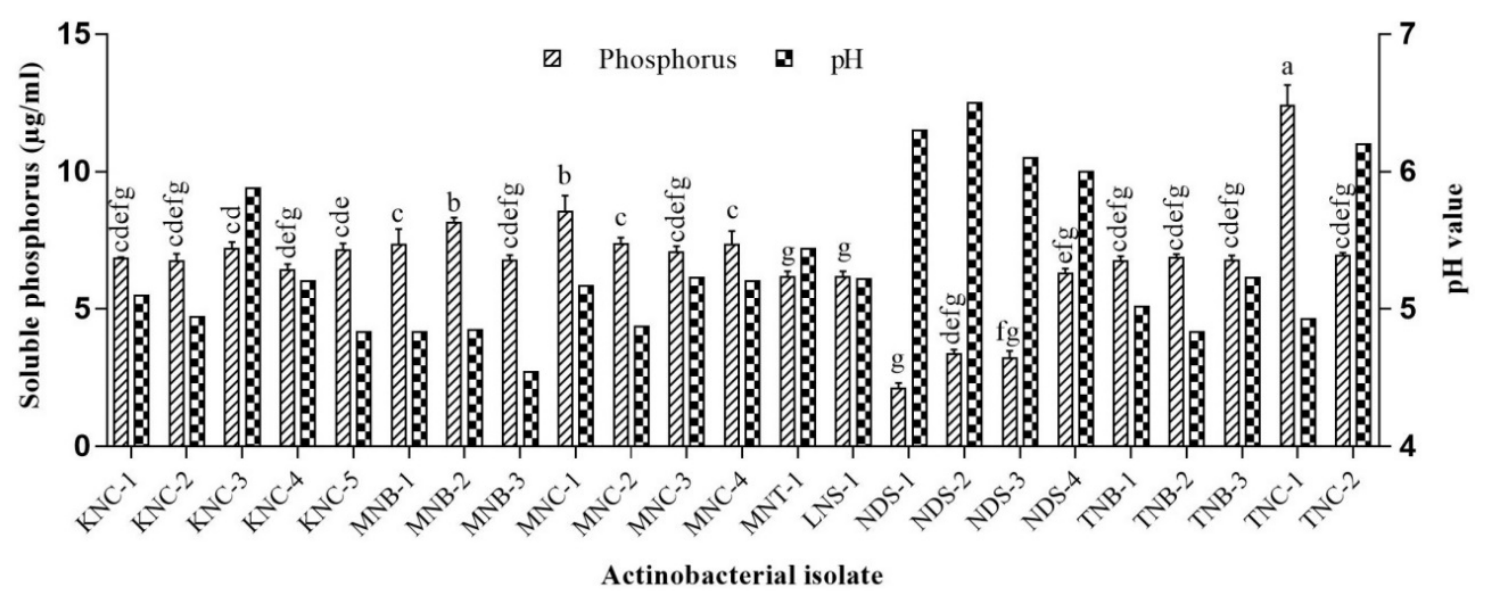

Figure 2. Determination of $\mathrm{P}$ solubilization and the evolution of $\mathrm{pH}$ in the culture supernatant of actinobacterial isolates. Means ( \pm standard deviations) with in the same graphic followed by different letters are significantly different at $p<0.05$. 
Isolates belonging to Streptomyces, Arthrobacter, Rhodococcus and Micromonospora genera have been reported to solubilize inorganic $\mathrm{P}[9,64,65]$, which is consistent with our results. El-Tarabily et al. [66] demonstrated that Micromonospora endolithica has the capacity to solubilize P and improve the growth of bean plants. However, there has been very limited research on the P-solubilizing efficiency of actinobacteria isolated from either marine or arid environments $[67,68]$.

Next, the isolates were screened for K solubilization ability (Table 2). Among all isolated actinobacteria, only one isolate was unable to form a significant zone of clearance on modified Aleksandrov agar plates, while six isolates (Streptomyces sp. KNC-2, Streptomyces sp. MNB-2, Streptomyces sp. MNC-3, Streptomyces sp. MNC-4, Streptomyces sp. TNC-1 and Streptomyces sp. TNC-2) showed relatively large zones of clearance. Currently, little information is available on K solubilization by rhizospheric actinobacteria. They may solubilize $\mathrm{K}$ and make it available to growing plants using various mechanisms, including the production of inorganic and organic acids and polysaccharides [69]. A wide range of rhizospheric bacteria have been reported as K solubilizers, including Burkholderia, Acidithiobacillus ferrooxidans [70], Arthrobacter sp. [71], Enterobacter hormaechei KSB-8 [72], Paenibacillus mucilaginosus and Paenibacillus glucanolyticus [73,74], and Aminobacter and Sphingomonas [75].

$\mathrm{N}$ fixation capacity was observed in $91 \%$ of the actinobacterial isolates (Table 2). Currently, there is no known N-fixing Streptomyces, other than the thermophilic, autotrophic Streptomyces thermoautotrophicus [76]. To our knowledge this is the first report of nitrogen fixation by the rare actinobacteria including Nocardioides, Actinomadura and Saccharomonospora. In addition, Frankia, a versatile $\mathrm{N}$-fixing actinobacterium, fixes $\mathrm{N}$ under both free-living and symbiotic conditions [10]. It infects the root cells of actinorhizal plants through either intracellular root-hair infection or intercellular root invasion [77]. Moreover, various other endophytic actinobacteria have the ability to fix $\mathrm{N}$, including Arthrobacter, Mycobacterium and Propionibacteria [78]. Additionally, other bacterial genera were reported as N-fixing actinobacteria, such as Agromyces, Microbacterium, Corynebacterium and Micromonospora isolated from root nodules of leguminous and actinorhizal plants [79].

Quantitative estimation of IAA production by actinobacterial isolates in the presence of L-tryptophan is shown in Figure 3. The IAA values ranged from 6.70 to $75.54 \mu \mathrm{g} / \mathrm{mL}$ after eight days of incubation. Isolate Streptomyces sp. MNC-1 isolated from the Merzouga desert produced the highest amount of IAA $(75.54 \mu \mathrm{g} / \mathrm{mL})$, followed by isolates: Streptomyces sp. MNB-2 $(50.32 \mu \mathrm{g} / \mathrm{mL})$, Saccharomonospora sp. LNS-1 $(49.46 \mu \mathrm{g} / \mathrm{mL})$, Streptomyces sp. MNT-1 $(46.41 \mu \mathrm{g} / \mathrm{mL})$ and Streptomyces sp. KNC-5 (41.92 $\mu \mathrm{g} / \mathrm{mL})$. Streptomyces MNC-1 has a similar level of IAA to the previously-reported work of Khamna et al. [46]. The lowest IAA production was observed for isolates Streptomyces sp. TNC-2 and Streptomyces sp. MNC-3 with $8.30 \mu \mathrm{g} / \mathrm{mL}$ and $6.70 \mu \mathrm{g} / \mathrm{mL}$, respectively. These results agree with those reported by Anwar et al. [76] and Rodrigues et al. [31]. Several Streptomyces species, such as Streptomyces olivaceoviridis, Streptomyces rimosus, Streptomyces rochei, Streptomyces griseoviridis, and Streptomyces lydi also have the ability to produce IAA and promote plant growth [80-82]. In fact, the majority of actinobacteria produce IAA, which is responsible for an increased number of adventitious roots and root exudates [83]. In addition, IAA can also act as a signal for the production of secondary metabolites and sporulation of actinobacteria $[84,85]$. 


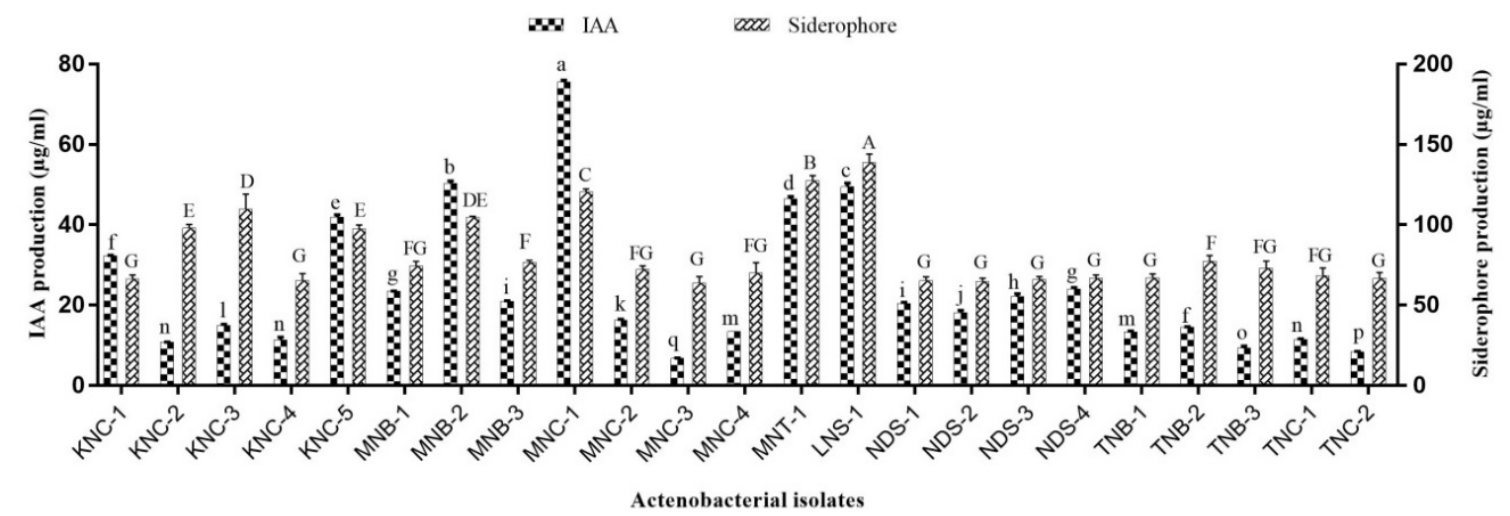

Figure 3. Indole acetic acid (IAA) and siderophore production by the isolated bacteria. Means ( \pm standard deviations) within the same graphic followed by different small case letters from IAA production and capital letters for siderophore production are significantly different at $p<0.05$.

The results of siderophore production in liquid medium by the isolated actinobacteria are shown in Figure 3. Isolate Saccharomonospora sp. LNS-1 was the highest siderophores producer $(138.92 \mu \mathrm{g} / \mathrm{mL})$, followed by isolates Streptomyces sp. MNT-1 (127.37 $\mu \mathrm{g} / \mathrm{mL})$ and Streptomyces sp. MNC-1 (120.35 $\mu \mathrm{g} / \mathrm{mL})$, while isolate Streptomyces sp. MNC-3 was the lowest siderophore producer $(63.80 \mu \mathrm{g} / \mathrm{mL})$. Siderophores help to satisfy an organism's iron needs by chelating it from inorganic sources and making it available to both bacteria and plants $[86,87]$. Siderophore production is implicated in growth promotion and in biocontrol of phytopathogens [33]. Numerous strains of actinobacteria have been reported as siderophore producers [13]. Oliveira et al. [88] found that Saccharopolyspora erythraea produces a hydroxamate type siderophore designated as erythrobactin. Similarly, the marine actinobacterium Citricoccus sp. KMM3890 produces a cyclic siderophore, nocardamine [89], while Actinomadura sp. DSMZ13491 produces the cyclic heptapeptide GE23077 with antibacterial activity [90]. Moreover, the novel heterobactin analog siderophore JBIR-16 is produced by Nocardia tenerifensis [91]. Kodani et al. [92] found that Streptomyces sp. TM-74 produces the siderophore tsukubachelin B.

Principal coordinate analysis (PCA) was used to select which isolates better expressed PGP activity (Figure 4). The two dimensions of the PCA (F1 and F2) were responsible for $91.19 \%$ of the total variation, with first axis accounting for $58.98 \%$ and the second axis for $32.21 \%$ of the variance. The PCA showed that isolates with higher activity in term of P solubilization, IAA and siderophores production were on the right of the first axis (F1), that is, they corresponded to isolates Streptomyces sp. MNC-1, Saccharomonospora sp. LNS-1, Streptomyces sp. MNT-1, Streptomyces sp. MNB-2, Streptomyces sp. KNC-5 and Streptomyces sp. KNC-3. Meanwhile, isolates with lower PGP activity are on the left in Figure 4. In comparison to the second axis, isolates Saccharomonospora sp. LNS-1, Streptomyces sp. MNT-1 and Streptomyces sp. KNC-5 displayed better production of IAA and siderophores and a medium level of P solubilization. In addition, isolates Streptomyces sp. MNC-1, Streptomyces sp. MNB-2 and Streptomyces sp. KNC-3 revealed better P solubilization than the other isolates. It's important to note that $\mathrm{P}$ solubilization ability is negatively correlated with IAA production. According to the results, we suggest that the most promising isolates were isolated from the desert soil, marine environment and rhizospheric soil of $C$. sativa. The interesting PGP activities of the promising isolates might be explained by their exhibition of a diversified metabolism and a strong enzymatic activity. 


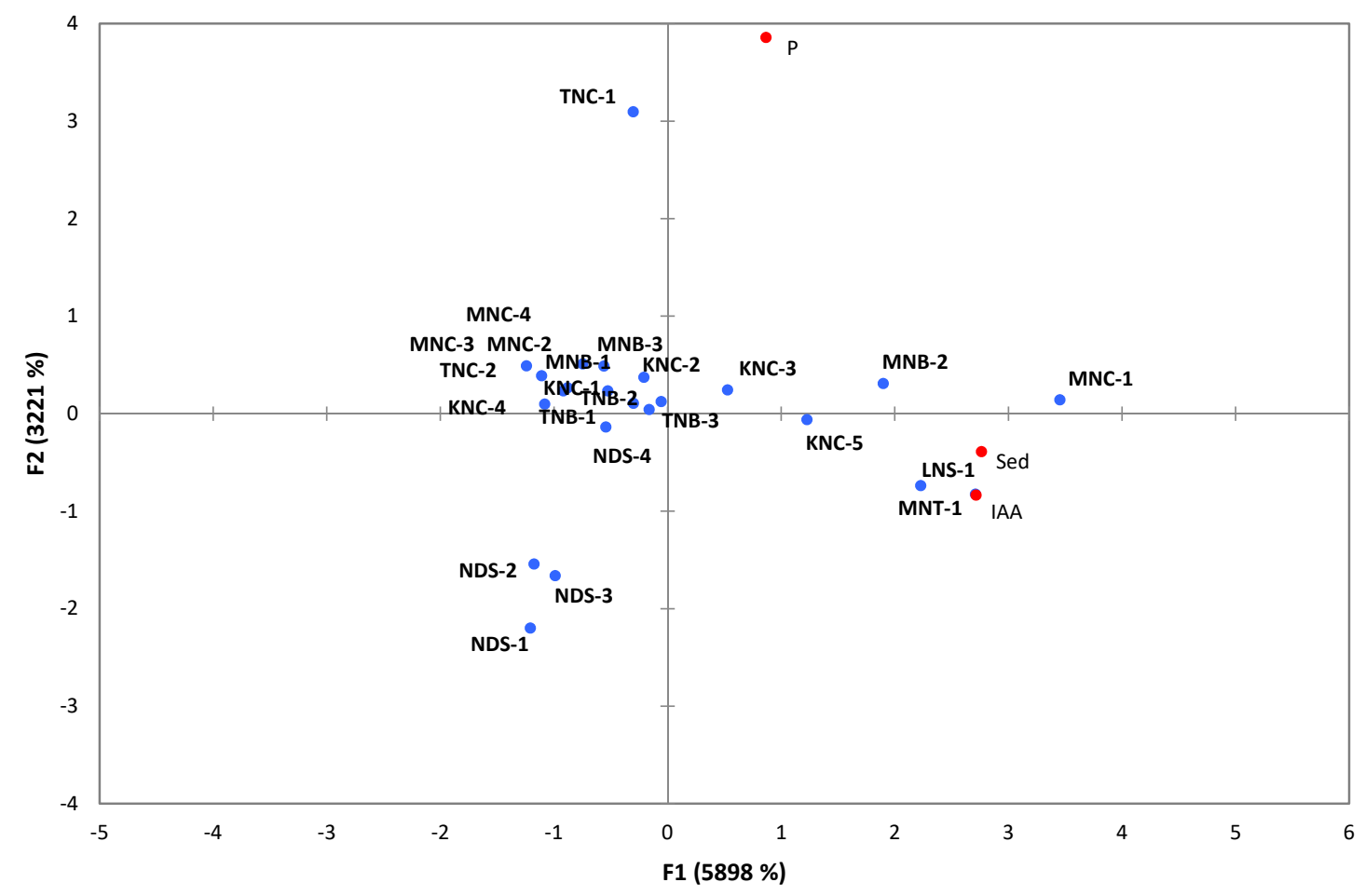

Figure 4. Principal coordinates analysis in term of phosphate solubilization (P), indole acetic acid (IAA) and siderophore (sid) production. The isolated actinobacteria are represented in blue; the PGP activities are presented in red.

\section{Conclusions}

Our findings revealed that the extreme ecosystems in Morocco are a rich source of valuable actinobacteria, especially for rare genera. This study is the first to report the discovery of Nocardioides, Saccharomonospora, Actinomadura, and Prauserella from a variety of extreme terrestrial and marine habitats in Morocco. Every actinobacterial isolate obtained exhibited distinctive PGP activities (i.e., IAA and siderophore production, $\mathrm{P}$ and $\mathrm{K}$ solubilization, and N-fixation), which can potentially be a promising microbial resource for optimizing green and sustainable agriculture in Morocco.

Author Contributions: Conceptualization, A.N.; methodology, A.N., A.R.; software, A.R., A.E.A.; formal analysis, A.N., A.R.; resources, F.E.K.; writing—original draft preparation, A.N., A.R., N.B.; writing—review and editing, B.R.G., Y.O., L.K. and M.H.; supervision, L.H.

Funding: This research received no external funding.

Acknowledgments: The principal author is grateful to all those who have participated in this work.

Conflicts of Interest: The authors have declared no conflict of interest.

\section{References}

1. Mohamed, H.; Miloud, B.; Zohra, F.; García-Arenzana, J.M.; Veloso, A.; Rodríguez-Couto, S. Isolation and Characterization of Actinobacteria from Algerian Sahara Soils with Antimicrobial Activities. Int. J. Mol. Cell. Med. 2017, 6, 109-120. [PubMed]

2. Loqman, S.; Bouizgarne, B.; Barka, E.A.; Clement, C.; Von Jan, M.; Spröer, C.; Klenk, H.-P.; Ouhdouch, Y. Streptomyces thinghirensis sp. nov., isolated from rhizosphere soil of Vitis vinifera. Int. J. Syst. Evol. Microbiol. 2009, 59, 3063-3067. [CrossRef] [PubMed]

3. Hamdali, H.; Virolle, M.J.; von Jan, M.; Sproer, C.; Klenk, H.-P.; Ouhdouch, Y. Streptomyces youssoufiensis sp. nov., isolated from a Moroccan phosphate mine. Int. J. Syst. Evol. Microbiol. 2011, 61, 1104-1108. [CrossRef] [PubMed] 
4. Barka, E.A.; Vatsa, P.; Sanchez, L.; Gaveau-Vaillant, N.; Jacquard, C.; Klenk, H.-P.; Clément, C.; Ouhdouch, Y.; van Wezel, G.P. Taxonomy, Physiology, and Natural Products of Actinobacteria. Microbiol. Mol. Biol. Rev. 2016, 80, 1-43. [CrossRef] [PubMed]

5. Steven, B.; Pollard, W.H.; Greer, C.W.; Whyte, L.G. Microbial diversity and activity through a permafrost/ground ice core profile from the Canadian high Arctic. Environ. Microbiol. 2008, 10, 3388-3403. [CrossRef] [PubMed]

6. Torsvik, V.; Øvreås, L. Microbial Diversity, Life Strategies, and Adaptation to Life in Extreme Soils. Microbiol. Extrem. Soils 2008, 13, 15-43.

7. Trenozhnikova, L.; Azizan, A. Discovery of Actinomycetes from Extreme Environments with Potential to Produce Novel Antibiotics. Central Asian J. Glob. Health 2018, 7, 1-15. [CrossRef]

8. Chianu, J.N.; Chianu, J.N.; Mairura, F. Mineral fertilizers in the farming systems of sub-Saharan Africa. A review. Agron. Sustain. Dev. 2012, 32, 545-566. [CrossRef]

9. Jog, R.; Nareshkumar, G.; Rajkumar, S. Plant growth promoting potential and soil enzyme production of the most abundant Streptomyces spp. from wheat rhizosphere. J. Appl. Microbiol. 2012, 113, 1154-1164. [CrossRef]

10. Sathya, A.; Vijayabharathi, R.; Gopalakrishnan, S. Plant growth-promoting actinobacteria: A new strategy for enhancing sustainable production and protection of grain legumes. 3 Biotech 2017, 7, 102. [CrossRef]

11. Olanrewaju, O.S.; Babalola, O.O. Streptomyces: Implications and interactions in plant growth promotion. Appl. Microbiol. Biotechnol. 2019, 103, 1179-1188. [CrossRef] [PubMed]

12. Tamreihao, K.; Ningthoujam, D.S.; Nimaichand, S.; Singh, E.S.; Reena, P.; Singh, S.H.; Nongthomba, U.; Singh, S.E. Biocontrol and plant growth promoting activities of a Streptomyces corchorusii strain UCR3-16 and preparation of powder formulation for application as biofertilizer agents for rice plant. Microbiol. Rep. 2016, 192, 260-270. [CrossRef] [PubMed]

13. Wang, W.; Qiu, Z.; Tan, H.; Cao, L. Siderophore production by actinobacteria. BioMetals 2014, $27,623-631$. [CrossRef] [PubMed]

14. Qin, S.; Li, W.J.; Dastager, S.G.; Hozzein, W.N. Editorial: Actinobacteria in Special and Extreme Habitats: Diversity, Function Roles, and Environmental Adaptations. Front. Microbiol. 2016, 7, 1203. [CrossRef] [PubMed]

15. Meklat, A.; Sabaou, N.; Zitouni, A.; Mathieu, F.; Lebrihi, A. Isolation, Taxonomy, and Antagonistic Properties of Halophilic Actinomycetes in Saharan Soils of Algeria. Appl. Environ. Microbiol. 2011, 77, 6710-6714. [CrossRef] [PubMed]

16. Gong, Y.; Bai, J.L.; Yang, H.T.; Zhang, W.D.; Xiong, Y.W.; Ding, P.; Qin, S. Phylogenetic diversity and investigation of plant growth-promoting traits of actinobacteria in coastal salt marsh plant rhizospheres from Jiangsu, China. Syst. Appl. Microbiol. 2018, 41, 516-527. [CrossRef] [PubMed]

17. Babavalian, H.; Amoozegar, M.A.; Pourbabaee, A.A.; Moghaddam, M.M.; Shakeri, F. Isolation and identification of moderately halophilic bacteria producing hydrolytic enzymes from the largest hypersaline playa in Iran. Microbiology 2013, 82, 466-474. [CrossRef]

18. Hozzein, W.N.; Li, W.J.; Ali, M.I.A.; Hammouda, O.; Mousa, A.S.; Xu, L.H.; Jiang, C.L. Nocardiopsis alkaliphila sp. nov., a novel alkaliphilic actinomycete isolated from desert soil in Egypt. Int. J. Syst. Evol. Microbiol. 2004, 54, 247-252. [CrossRef]

19. Driche, E.H.; Sabaou, N.; Bijani, C.; Zitouni, A.; Pont, F.; Mathieu, F.; Badji, B. Streptomyces sp. AT37 isolated from a Saharan soil produces a furanone derivative active against multidrug-resistant Staphylococcus aureus. World J. Microbiol. Biotechnol. 2017, 33, 105. [CrossRef]

20. Weisburg, W.; Barns, S.; Pelletier, D.; Lane, D. 16S ribosomal DNA amplification for phylogenetic studyitle. J. Bacteriol. 1991, 173, 697-703. [CrossRef]

21. Pawlowski, J.; Holzmann, M. Molecular phylogeny of Foraminifera a review. Eur. J. Protistol. 2002, 38, 1-10. [CrossRef]

22. Kim, O.S.; Cho, Y.J.; Lee, K.; Yoon, S.H.; Kim, M.; Na, H.; Park, S.C.; Jeon, Y.S.; Lee, J.H.; Yi, H.; et al. Introducing EzTaxon-e: A prokaryotic 16S rRNA gene sequence database with phylotypes that represent uncultured species. Int. J. Syst. Evol. Microbiol. 2012, 62, 716-721. [CrossRef] [PubMed]

23. Larkin, M.; Blackshields, G.; Brown, N.; Chenna, R.; Mcgettigan, P.; Mc William, H.; Valentin, F.; Wallace, I.; Wilm, A.; López, R.; et al. Clustal W and Clustal X version 2.0. Bioinformatics 2007, 23, 2947-2948. [CrossRef] [PubMed] 
24. Tamura, K.; Peterson, D.; Peterson, N.; Stecher, G.; Nei, M.; Kumar, S. MEGA5: Molecular Evolutionary Genetics Analysis Using Maximum Likelihood, Evolutionary Distance, and Maximum Parsimony Methods. Mol. Biol. Evol. 2011, 28, 2731-2739. [CrossRef] [PubMed]

25. Felsenstein, J. Evolutionary trees from DNA sequences: A maximum likelihood approach. J. Mol. Evol. 1981, 17, 368-376. [CrossRef] [PubMed]

26. Bechtaoui, N.; Raklami, A.; Tahiri, A.-I.; Benidire, L.; El Alaoui, A.; Meddich, A.; Göttfert, M.; Oufdou, K. Characterization of plant growth promoting rhizobacteria and their benefits on growth and phosphate nutrition of faba bean and wheat. Biol. Open 2019, 8, bio043968. [CrossRef] [PubMed]

27. Nagul, E.A.; McKelvie, I.D.; Worsfold, P.; Kolev, S.D. The molybdenum blue reaction for the determination of orthophosphate revisited: Opening the black box. Anal. Chim. Acta 2015, 890, 60-82. [CrossRef]

28. Meena, V.S.; Maurya, B.R.; Verma, J.P.; Aeron, A.; Kumar, A.; Kim, K.; Bajpai, V.K. Potassium solubilizing rhizobacteria (KSR): Isolation, identification, and K-release dynamics from waste mica. Ecol. Eng. 2015, 81, 340-347. [CrossRef]

29. Dahal, B.; NandaKafle, G.; Perkins, L.; Brözel, V.S. Diversity of free-Living nitrogen fixing Streptomyces in soils of the badlands of South Dakota. Microbiol. Rep. 2016, 195, 31-39. [CrossRef]

30. Sachdev, D.P.; Chaudhari, H.G.; Kasture, V.M.; Dhavale, D.D.; Chopade, B.A. Isolation and characterization of indole acetic acid (IAA) producing Klebsiella pneumoniae strains from rhizosphere of wheat (Triticum aestivum) and their effect on plant growth. Indian J. Exp. Biol. 2009, 47, 993-1000.

31. Rodrigues, A.A.; Araújo, M.V.F.; Soares, M.D.S.; De Oliveira, B.F.R.; Sibov, S.T.; Vieira, J.D.G. Isolation and Screening for Multi-trait Plant Growth Promoting Actinobacteria From Organic Sugarcane Rhizosphere. Int. J. Microbiol. Res. 2018, 10, 1193. [CrossRef]

32. Hu, Q.-P.; Xu, J.-G. A simple double-layered chrome azurol S agar (SD-CASA) plate assay to optimize the production of siderophores by a potential biocontrol agent Bacillus. African J. Microbiol. Res. 2011, 5, $4321-4327$.

33. Arora, N.K.; Verma, M. Modified microplate method for rapid and efficient estimation of siderophore produced by bacteria. 3 Biotech 2017, 7, 381. [CrossRef] [PubMed]

34. Baakza, A.; Dave, B.P.; Dube, H.C. Chemical nature, ligand denticity and quantification of fungal siderophores. Indian J. Exp. Biol. 2004, 42, 96-105. [PubMed]

35. Marcoux, E.; Belkabir, A.; Gibson, H.L.; Lentz, D.; Ruffet, G. Draa Sfar, Morocco: A Visean (331 Ma) pyrrhotite-rich, polymetallic volcanogenic massive sulphide deposit in a Hercynian sediment-dominant terrane. Ore Geol. Rev. 2008, 33, 307-328. [CrossRef]

36. Albarracin, V.H.; Alonso-Vega, P.; Trujillo, M.E.; Amoroso, M.J.; Abate, C.M. Amycolatopsis tucumanensis sp. nov., a copper-resistant actinobacterium isolated from polluted sediments. Int. J. Syst. Evol. Microbiol. 2010, 60, 397-401. [CrossRef]

37. Ali, N.; Dashti, N.; Al-Mailem, D.; Eliyas, M.; Radwan, S. Indigenous soil bacteria with the combined potential for hydrocarbon consumption and heavy metal resistance. Environ. Sci. Pollut. Res. 2012, 19, 812-820. [CrossRef]

38. Richards, J.W.; Krumholz, G.D.; Chval, M.S.; Tisa, L.S. Heavy Metal Resistance Patterns of Frankia Strains. Appl. Environ. Microbiol. 2002, 68, 923-927. [CrossRef]

39. Köberl, M.; Müller, H.; Ramadan, E.M.; Berg, G. Desert Farming Benefits from Microbial Potential in Arid Soils and Promotes Diversity and Plant Health. PLoS ONE 2011, 6, e24452. [CrossRef]

40. Harwani, D. Biodiversity of Rare Thermophilic Actinomycetes in the Great Indian Thar Desert: An Overview. Indo Am. J. Pharm. Res. 2013, 3.

41. Santhanam, R.; Rong, X.; Huang, Y.; Andrews, B.A.; Asenjo, J.A.; Goodfellow, M. Streptomyces bullii sp. nov., isolated from a hyper-arid Atacama Desert soil. Antonie Van Leeuwenhoek 2013, 103, 367-373. [CrossRef] [PubMed]

42. Kurapova, A.I.; Zenova, G.M.; Sudnitsyn, I.I.; Kizilova, A.K.; Manucharova, N.A.; Norovsuren, Z.; Zvyagintsev, D.G. Thermotolerant and thermophilic actinomycetes from soils of Mongolia desert steppe zone. Microbiology 2012, 81, 98-108. [CrossRef]

43. Lahoum, A.; Aouiche, A.; Bouras, N.; Verheecke, C.; Klenk, H.-P.; Sabaou, N.; Mathieu, F. Antifungal activity of a Saharan strain of Actinomadura sp. ACD1 against toxigenic fungi and other pathogenic microorganisms. J. Mycol. Médicale 2016, 26, 193-200. [CrossRef] [PubMed] 
44. Badji, B.; Mostefaoui, A.; Sabaou, N.; Mathieu, F.; Lebrihi, A. Identification of a new strain of Actinomadura isolated from Saharan soil and partial characterization of its antifungal compounds. Afr. J. Biotechnol. 2011, 10, 13878-13886.

45. Zitouni, A.; Boudjella, H.; Lamari, L.; Badji, B.; Mathieu, F.; Lebrihi, A.; Sabaou, N. Nocardiopsis and Saccharothrix genera in Saharan soils in Algeria: Isolation, biological activities and partial characterization of antibiotics. Res. Microbiol. 2005, 156, 984-993. [CrossRef]

46. Khamna, S.; Yokota, A.; Lumyong, S. Actinomycetes isolated from medicinal plant rhizosphere soils: Diversity and screening of antifungal compounds, indole-3-acetic acid and siderophore production. World J. Microbiol. Biotechnol. 2009, 25, 649-655. [CrossRef]

47. Aouar, L.; Lerat, S.; Ouffroukh, A.; Boulahrouf, A.; Beaulieu, C. Taxonomic identification of rhizospheric actinobacteria isolated from Algerian semi-arid soil exhibiting antagonistic activities against plant fungal pathogens. Can. J. Plant Pathol. 2012, 34, 165-176. [CrossRef]

48. Solans, M.; Scervino, J.M.; Messuti, M.I.; Vobis, G.; Wall, L.G. Potential biocontrol actinobacteria: Rhizospheric isolates from the Argentine Pampas lowlands legumes. J. Basic Microbiol. 2016, 56, 1289-1298. [CrossRef]

49. Lozupone, C.A.; Knight, R. Global patterns in bacterial diversity. Proc. Natl. Acad. Sci. USA 2007, 104, 11436-11440. [CrossRef]

50. Lindh, M.V.; Riemann, L.; Baltar, F.; Romero-Oliva, C.; Salomon, P.S.; Granéli, E.; Pinhassi, J. Consequences of increased temperature and acidification on bacterioplankton community composition during a mesocosm spring bloom in the Baltic Sea. Environ. Microbiol. Rep. 2013, 5, 252-262. [CrossRef]

51. Gong, J.; Shi, F.; Ma, B.; Dong, J.; Pachiadaki, M.; Zhang, X.; Edgcomb, V.P. Depth shapes $\alpha$ - and $\beta$-diversities of microbial eukaryotes in surficial sediments of coastal ecosystems. Environ. Microbiol. 2015, 17, 3722-3737. [CrossRef] [PubMed]

52. Ouchari, L.; Boukeskasse, A.; Bouizgarne, B.; Ouhdouch, Y. Antimicrobial potential of actinomycetes isolated from the unexplored hot Merzouga desert and their taxonomic diversity. Biol. Open 2019, 8, bio035410. [CrossRef] [PubMed]

53. Subramani, R.; Aalbersberg, W. Marine actinomycetes: An ongoing source of novel bioactive metabolites. Microbiol. Res. 2012, 167, 571-580. [CrossRef] [PubMed]

54. Abdelmohsen, U.R.; Pimentel-Elardo, S.M.; Hanora, A.; Radwan, M.; Abou-El-Ela, S.H.; Ahmed, S.; Hentschel, U. Isolation, Phylogenetic Analysis and Anti-infective Activity Screening of Marine Sponge-Associated Actinomycetes. Mar. Drugs 2010, 8, 399-412. [CrossRef] [PubMed]

55. Maldonado, L.A.; Stach, J.E.M.; Pathom-aree, W.; Ward, A.C.; Bull, A.T.; Goodfellow, M. Diversity of cultivable actinobacteria in geographically widespread marine sediments. Antonie Van Leeuwenhoek 2005, 87, 11-18. [CrossRef] [PubMed]

56. Kim, T.K.; Hewavitharana, A.K.; Shaw, P.N.; Fuerst, J.A. Discovery of a New Source of Rifamycin Antibiotics in Marine Sponge Actinobacteria by Phylogenetic Prediction. Appl. Environ. Microbiol. 2006, 72, 2118-2125. [CrossRef] [PubMed]

57. Mohanraj, D.; Bharathi, S.; Radhakrishnan, M.; Balagurunathan, R. Bioprospecting of actinobacteria from Yelagiri hills with special reference to antibacterial activity. J. Chem. Pharm. Res 2011, 3, 439-446.

58. Dalisay, D.S.; Williams, D.E.; Wang, X.L.; Centko, R.; Chen, J.; Andersen, R.J. Marine Sediment-Derived Streptomyces Bacteria from British Columbia, Canada Are a Promising Microbiota Resource for the Discovery of Antimicrobial Natural Products. PLoS ONE 2013, 8, e77078. [CrossRef]

59. Dharmaraj, S. Marine Streptomyces as a novel source of bioactive substances. World J. Microbiol. Biotechnol. 2010, 26, 2123-2139. [CrossRef]

60. Ramesh, S.; Mathivanan, N. Screening of marine actinomycetes isolated from the Bay of Bengal, India for antimicrobial activity and industrial enzymes. World J. Microbiol. Biotechnol. 2009, 25, 2103-2111. [CrossRef]

61. Matos, A.D.M.; Gomez, I.C.P.; Nietsche, S.; Xavier, A.A.; Gomes, W.S.; Dos Santos Neto, J.A.; Pereira, M.C.T. Phosphate solubilization by endophytic bacteria isolated from banana trees. An. Acad. Bras. Cienc. 2017, 89, 2945-2954. [CrossRef] [PubMed]

62. Nautiyal, C.S.; Bhadauria, S.; Kumar, P.; Lal, H.; Mondal, R.; Verma, D. Stress induced phosphate solubilization in bacteria isolated from alkaline soils. FEMS Microbiol. Lett. 2000, 182, 291-296. [CrossRef]

63. De Oliveira Mendes, G.; Moreira de Freitas, A.L.; Liparini Pereira, O.; Ribeiro da Silva, I.; Bojkov Vassilev, N.; Dutra Costa, M. Mechanisms of phosphate solubilization by fungal isolates when exposed to different $\mathrm{P}$ sources. Ann. Microbiol. 2014, 64, 239-249. [CrossRef] 
64. Chen, Y.P.; Rekha, P.D.; Arun, A.B.; Shen, F.T.; Lai, W.-A.; Young, C.C. Phosphate solubilizing bacteria from subtropical soil and their tricalcium phosphate solubilizing abilities. Appl. Soil Ecol. 2006, 34, $33-41$. [CrossRef]

65. Hamdali, H.; Bouizgarne, B.; Hafidi, M.; Lebrihi, A.; Virolle, M.J.; Ouhdouch, Y. Screening for rock phosphate solubilizing Actinomycetes from Moroccan phosphate mines. Appl. Soil Ecol. 2008, 38, 12-19. [CrossRef]

66. El-Tarabily, K.A.; Nassar, A.H.; Hardy, G.E.S.J.; Sivasithamparam, K. Plant growth promotion and biological control of Pythium aphanidermatum, a pathogen of cucumber, by endophytic actinomycetes. J. Appl. Microbiol. 2009, 106, 13-26. [CrossRef] [PubMed]

67. Sharma, S.B.; Sayyed, R.Z.; Trivedi, M.H.; Gobi, T.A. Phosphate solubilizing microbes: Sustainable approach for managing phosphorus deficiency in agricultural soils. Springerplus 2013, 2, 587. [CrossRef]

68. Dastager, S.G.; Damare, S. Marine Actinobacteria Showing Phosphate-Solubilizing Efficiency in Chorao Island, Goa, India. Curr. Microbiol. 2013, 66, 421-427. [CrossRef]

69. Etesami, H.; Emami, S.; Alikhani, H.A. Potassium solubilizing bacteria (KSB): Mechanisms, promotion of plant growth, and future prospects-A review. J. Soil Sci. Plant Nutr. 2017, 17, 897-911. [CrossRef]

70. Sheng, X.F.; He, L.Y. Solubilization of potassium-bearing minerals by a wild-type strain of Bacillus edaphicus and its mutants and increased potassium uptake by wheat. Can. J. Microbiol. 2006, 52, 66-72. [CrossRef]

71. Zarjani, K.J.; Aliasgharzad, N.; Oustan, S.; Emadi, M.; Ahmadi, A. Isolation and characterization of potassium solubilizing bacteria in some Iranian soils. Arch. Agron. Soil Sci. 2013, 59, 1713-1723. [CrossRef]

72. Prajapati, K.; Sharma, M.C.; Modi, H.A. Growth Promoting Effect of Potassium Solubilizing Microorganisms on Okra (Abelmoscus Esculantus). Int. J. Agric. Sci. 2013, 31, 181-186.

73. Liu, D.; Lian, B.; Dong, H. Isolation of Paenibacillus sp. and Assessment of its Potential for Enhancing Mineral Weathering. Geomicrobiol. J. 2012, 29, 413-421. [CrossRef]

74. Suseela, R.B.; Srinivasan, V.; Sangeeth, K.P. Paenibacillus glucanolyticus, a promising potassium solubilizing bacterium isolated from black pepper (Piper nigrum L.) rhizosphere. J. Spices Aromat. Crop. 2012, 21, 118-124.

75. Uroz, S.; Calvaruso, C.; Turpault, M.P.; Pierrat, J.C.; Mustin, C.; Frey-Klett, P. Effect of the Mycorrhizosphere on the Genotypic and Metabolic Diversity of the Bacterial Communities Involved in Mineral Weathering in a Forest Soil. Appl. Environ. Microbiol. 2007, 73, 3019-3027. [CrossRef]

76. Ribbe, M.; Gadkari, D.; Meyer, O. N 2 Fixation by Streptomyces thermoautotrophicus Involves a Molybdenum-Dinitrogenase and a Manganese-Superoxide Oxidoreductase That Couple N 2 Reduction to the Oxidation of Superoxide Produced from O 2 by a Molybdenum-CO Dehydrogenase. J. Biol. Chem. 1997, 272, 26627-26633. [CrossRef] [PubMed]

77. Benson, D.R.; Silvester, W.B. Biology of Frankia strains, actinomycete symbionts of actinorhizal plants. Microbiol. Rev. 1993, 57, 293-319.

78. Sellstedt, A.; Richau, K.H. Aspects of nitrogen-fixing Actinobacteria, in particular free-living and symbiotic Frankia. FEMS Microbiol. Lett. 2013, 342, 179-186. [CrossRef]

79. Gtari, M.; Ghodhbane-Gtari, F.; Nouioui, I.; Beauchemin, N.; Tisa, L.S. Phylogenetic perspectives of nitrogen-fixing actinobacteria. Arch. Microbiol. 2012, 194, 3-11. [CrossRef]

80. Anwar, S.; Ali, B.; Sajid, I. Screening of Rhizospheric Actinomycetes for Various In-vitro and In-vivo Plant Growth Promoting (PGP) Traits and for Agroactive Compounds. Front. Microbiol. 2016, 7, 1334-1345. [CrossRef]

81. Tsavkelova, E.A.; Klimova, S.Y.; Cherdyntseva, T.A.; Netrusov, A.I. Microbial producers of plant growth stimulators and their practical use: A review. Appl. Biochem. Microbiol. 2006, 42, 117-126. [CrossRef]

82. El-Tarabily, K.A.; Nassar, A.H.; Sivasithamparam, K. Promotion of growth of bean (Phaseolus vulgaris L.) in a calcareous soil by a phosphate-solubilizing, rhizosphere-competent isolate of Micromonospora endolithica. Appl. Soil Ecol. 2008, 39, 161-171. [CrossRef]

83. El-Tarabily, K.A. Promotion of tomato (Lycopersicon esculentum Mill.) plant growth by rhizosphere competent 1-aminocyclopropane-1-carboxylic acid deaminase-producing streptomycete actinomycetes. Plant Soil 2008, 308, 161-174. [CrossRef]

84. Duca, D.; Lorv, J.; Patten, C.L.; Rose, D.; Glick, B.R. Indole-3-acetic acid in plant-microbe interactions. Antonie Van Leeuwenhoek 2014, 106, 85-125. [CrossRef] [PubMed]

85. Glick, B.R. Plant Growth-Promoting Bacteria: Mechanisms and Applications. Scientifica 2012, 2012, 1-15. [CrossRef] [PubMed] 
86. Arora, N.K.; Tewari, S.; Singh, R. Multifaceted Plant-Associated Microbes and Their Mechanisms Diminish the Concept of Direct and Indirect PGPRs. In Plant Microbe Symbiosis: Fundamentals and Advances; Springer: New Delhi, India, 2013; pp. 411-449.

87. Singh, R.; Pandey, K.D.; Monika, S.; Kumar, A. PGPR Isolates from the Rhizosphere of Vegetable Crop Momordica charantia: Characterization and Application as Biofertilizer. Int. J. Curr. Microbiol. Appl. Sci. 2017, 6, 1789-1802.

88. Oliveira, P.H.; Batagov, A.; Ward, J.; Baganz, F.; Krabben, P. Identification of erythrobactin, a hydroxamate-type siderophore produced by Saccharopolyspora erythraea. Lett. Appl. Microbiol. 2006, 42, 375-380. [CrossRef] [PubMed]

89. Kalinovskaya, N.I.; Romanenko, L.A.; Irisawa, T.; Ermakova, S.P.; Kalinovsky, A.I. Marine isolate Citricoccus sp. KMM 3890 as a source of a cyclic siderophore nocardamine with antitumor activity. Microbiol. Res. 2011, 166, 654-661. [CrossRef]

90. Mazzei, E.; Iorio, M.; Maffioli, S.I.; Sosio, M.; Donadio, S. Characterization of madurastatin C1, a novel siderophore from Actinomadura sp. J. Antibiot. 2012, 65, 267-269. [CrossRef]

91. Mukai, A.; Komaki, H.; Takagi, M.; Shin-ya, K. Novel siderophore, JBIR-16, isolated from Nocardia tenerifensis NBRC 101015. J. Antibiot. 2009, 62, 601-603. [CrossRef]

92. Kodani, S.; Kobayakawa, F.; Hidaki, M. Isolation and structure determination of new siderophore tsukubachelin B from Streptomyces sp. TM-74. Nat. Prod. Res. 2013, 27, 775-781. [CrossRef] [PubMed]

(C) 2019 by the authors. Licensee MDPI, Basel, Switzerland. This article is an open access article distributed under the terms and conditions of the Creative Commons Attribution (CC BY) license (http://creativecommons.org/licenses/by/4.0/). 